\title{
The Mediating Effect of e-Satisfaction and Trust on the Influence of Brand Image and e-Loyalty
}

\author{
Giovano Melvernus Hendrawan \\ Soegijapranata Catholic University \\ giovanohendrawan@gmail.com \\ Maria Yosephine Dwi Hayu Agustini \\ Soegijapranata Catholic University \\ mariaagustini84@yahoo.com
}

\begin{abstract}
Loyalty to an e-commerce is difficult to be gained even though factors influencing it have been studied by many. Among others, brand image, e-satisfaction, and trust are the factors. This study aims at analyzing mediating effect of e-satisfaction and trust on the influence of brand image and e-loyalty in the case of Tokopedia, an e-marketplace with strong brand image in Indonesia. Questionnaires to 114 buyers who are categorized as generation $\mathrm{Y}$ and $\mathrm{Z}$ were distributed using Google form. The Mediating Regression Analysis (MRA) test was applied to see mediating effect of e-satisfaction and trust. The data were tested for their normality, multicollinearity, and heteroscedasticity before the regression. The results indicate only brand image and e-satisfaction that affect e-loyalty positively and significantly. E-satisfaction is also found to mediate brand image and e-loyalty. Since trust is insignificantly affect e-loyalty, it thus does not mediate brand image and e-loyalty.
\end{abstract}

Keywords: brand image, e-loyalty, e-satisfaction, e-marketplace, trust.

\section{INTRODUCTION}

Online shopping has currently become common way for transactions. The online transactions in Indonesia have reached 19 trillion rupiahs each month in 2019, which is approximately 60 percent higher than those in 2018 (Kontan, 2019). With 62 e-marketplaces available in Indonesia by 2020 (Tempo, 2019), consumers can have options and choose the one that is most fit their needs. Since it is easy for a consumer to move between one e-marketplace to another, intention to revisit an e-marketplace or to consider repurchasing from it in the future is relatively low. Cyr, et al (2005) related such intention to e-loyalty. Consequently, competition among e-marketplaces for gaining larger market share is higher. 
Among others, Tokopedia, Shopee, Bukalapak, Lazada, and Blibli are the five most visited e-marketplaces (iPrice, 2019). After being in the top rank for years according to the annual web visit, Tokopedia has been experiencing decline in the web visit since 2018. Even though it still maintains the top position, the decline can be the signal alarming problem in consumer loyalty in particularly on revisiting the web and repurchasing from it (e-loyalty).

Studies show many factors influencing e-loyalty. Previous research indicated that brand image affects customer's purchase decision in an e-marketplace. As Kotler and Keller (2016) stated that brand is a promise of the company to its consumers. It sets consumers' expectations and reduces their risk that eventually leads to customer loyalty. A good brand image creates perception on whether the e-marketplace delivers satisfaction and trustworthy which then generates loyalty over the consumers. Underdeveloped and less presented brand image leads to loss of customers as they may be unsatisfied and ultimately generates low loyalty and commitment to the organization's market offerings (Ogba \& Tan, 2009).

e-Satisfaction referring to satisfaction over e-commerce (Anderson \& Srinivasan, 2003) influences e-loyalty (Ahmad et al, 2017; Pereira et al, 2016; Tang \& Huang, 2015). Satisfied customers are likely to repurchase from a business that has satisfied them during their prior shopping through the Internet (Shankar, et al 2003). However, as Bilgihan (2016) found, customers who do not trust the e-commerce would not be loyal to it. In other words, trust affects e-loyalty. Azam (2015) warned that it is crucial for e-commerce to consider trust in developing e-loyalty of their customers.

Studies show inconsistent results of the influence of brand image, e-satisfaction, and trust on e-loyalty. Hapsari et al (2017), Al-dweeri et al (2017), and Sadeghi et al (2018) respectively found that brand image, e-satisfaction, and trust do not affect e-loyalty. This 
inconsistent findings are possibly due to different context in terms of either geographical or in industry.

Other studies indicate existence of indirect effect of brand image to e-loyalty since brand loyalty affect also e-satisfaction and trust. Ogba and Tan (2009) noted that brand image has a positive impact on customer expression of satisfaction and loyalty. Moreover, Lien et al (2015) found that brand image has a positive effect to trust. Thus, it can be stated that e-satisfaction and trust allegedly mediate the effect of brand image to e-loyalty. This research aims to analyze the influence of brand image, e-satisfaction, and trust to e-loyalty and to find out whether esatisfaction and trust have mediating effect of brand image to e-loyalty. This aim is applied on the case of Tokopedia for it to be able to maintain its top position by increasing customers' loyalty.

\section{LITERATURE REVIEW}

\section{e-Loyalty}

Customer loyalty is considerably important and many firms adopt customer loyalty programs to create or increase loyalty of their customers. Such program gain its popularity since it can increase profit significantly (Uncles, Dowling, \& Hammond, 2003). As Uncles, Dowling, and Hammond noted, the programs aim at increasing sales revenues resulted from higher purchase/usage level or broader range of products brought as well as at building a closer bond between the brand and current customers. Once customers are loyal to a brand or product, they will constantly purchase the same brand or product. Thus, customer loyalty is defined as commitment held deeply to rebuy or re-patronize a particular product constantly in the future, regardless situational influences and marketing efforts having the potential to induce switching behavior (Oliver, 2010). This definition has been used widely in research on e-loyalty. 
e-Loyalty is an intention to revisit a website or to consider purchasing from it in the future (Cyr et al, 2005). It shows commitment of consumer to rebuy or patronize a product or service constantly in the future regardless the situations and marketing efforts that may induce switching behavior (Oliver, 2010; Chiu et al, 2009). It thus is considerably a favorable attitude toward an e-commerce that results in repeat buying behavior (Toufaily et al, 2013).

According to Li et al. (2015), loyal customers show repeat buying behavior in which they purchase products or services from the same e-commerce repeatedly. They also contribute in bringing new customers by engaging in positive word-of-mouth marketing. Toufaily et al (2013) wrapped up the benefits generated from e-loyalty. Besides it increases customer profitability, the share of wallet, frequency of website purchase, number of visits, willingness to pay more and to purchase on the site, total satisfaction in the online experience, cross-selling, customer retention, it also reduces sensitivity to price and alternative search as well as create positive word of mouth.

Previous researchers revealed several factors affecting e-loyalty. Among others, brand image (Kwon \& Lennon, 2009; Ogba \& Tan, 2009), e-satisfaction (Valvi \& West, 2013; Anderson \& Srinivasan, 2003), and trust (Flavián et al, 2006; Lee \& Sohn, 2004) are those reseached widely.

\section{e-Loyalty and Brand Image}

Brand image is set of associations to a brand hold in customer mind (Keller, 2013). It represents reasoned or emotional perceptions attached to a brand (Cretu, 2007; Low et al 2000). According to Kotler \& Keller (2016), brand is company's promise to its customers, sets the customer expectations, and reduces their risk which eventually leads to customer loyalty.

The influence of brand image to e-loyalty has been revealed in many studies. Brand image has a positive impact on e-loyalty (Lien et al., 2015; Wu, 2011; Kwon \& Lennon, 2009; 
Ogba \& Tan, 2009). As Aghekyan-Simonian, et al (2012) found, brand image influences consumers' online purchase intentions which is the consequence of e-loyalty. AghekyanSimonian, et al (2012) also stated that robust brand image is the most valuable asset for online retailers. It assists consumers in deciding whether to buy or not to buy the brand and influences their repurchase behavior (Bian \& Moutinho, 2011) that eventually leads to e-loyalty (Yun \& Good, 2007).

Moreover, Ogba and Tan (2009) noted that brand is the key to maintaining a position in the market since brand with strong identity can be recognized and relied on by customers. A well-managed brand expands market share (O’Neill \& Xiao, 2006) since positive brand image helps the company to build the brand's position, strengthen the brand's market performance, and preserve the brand from the competition.

\section{e-Loyalty and e-Satiafaction}

Satisfaction is a degree to which level of fulfillment is delightful or not delightful (Oliver, 2010). It leads to customers' repurchase intentions (Chang et al, 2009; Lee et al, 2009; Tsai et al, 2006). Customer satisfaction in the contexts of e-commerce which is called as e-satisfaction (Anderson \& Srinivasan, 2003) is more complex (Tang \& Huang, 2015). Anderson and Srinivasan (2003) defined e-satisfaction as contentment of the customer with respect to their previous purchasing experience given by e-commerce.

It is very important for e-commerce to increase customer satisfaction in order to maintain its customer loyalty (Hsu et al, 2013). According to Ribbink, et al (2004), satisfaction gained from an e-commerce is very important for customers in deciding whether to continue the relationship with the e-commerce or not. Satisfied customers tend to repurchase from the e-commerce that satisfied them in their prior purchase (Shankar, et al 2003). On the other side, dissatisfied customers tend to decline any programs for building closer relationship by the e-commerce and to take steps to release dependence from it. 
Studies revealed the influence of e-satisfaction on e-loyalty (Ahmad et al, 2017; Pereira et al, 2016; Tang \& Huang, 2015; Valvi \& West, 2013; Anderson \& Srinivasan, 2003). E-satisfaction has been assumed to be a natural antecedent to e-loyalty (Anderson \& Srinivasan, 2003). Studies found such influence happens in several geographical contexts, such as Taiwan (Tang \& Huang, 2015), Europe (Audrain-Pontevia, et al., 2013), China (Ziaullah, et al., 2014), and Japan (Moriuchi \& Takahashi, 2016).

The study of Ogba and Tan (2009) found that customer expression of satisfaction is affected by brand image. This indicates possibility of e-satisfaction in mediating the effect of brand image toward e-loyalty.

\section{e-Loyalty and Trust}

In the context of e-commerce, trust can be defined as a customer's confidence and belief that their expectations on an online business is met (Valvi \& West, 2013). According to Reicheld and Schefter (2000), trust is a matter in e-commerce since customers rely on images and promises due to the increase of distance, risk and uncertainties. Yousafzai et al (2003) stated that risk perceived by customers can be reduced by building relationships based on trust. Online consumers expect ecommerce to have willingness and is able to act based on the consumers' interests, to be truthful in transactions by for example keeping consumers' personal information safe, and to deliver the ordered goods as promised (Tang \& Huang, 2015).

Many studies have revealed direct effect of trust to e-loyalty (Bilgihan, 2016; Azam, 2015; Carter et al., 2014; Hsu et al., 2013; Ribbink et al., 2004). Customers who do not trust ecommerce will not be loyal to them even though they are generally satisfied (Anderson \& Srinivasan, 2003). In other words, trust provided by e-commerce can increase e-loyalty and lead to sustainable transaction intentions (Huang, 2008) or increase customers' repurchase intention (Safa \& Von Solms, 2016). 
Trust can be effectively stimulated by providing a safe, convincing, and reliable website (Yousafzai et al, 2003). Thus building a trusted website is the main problem for brands because consumers likely to purchase from and stay loyal to only websites they can trust (Bilgihan, 2016). Companies can therefore increase e-loyalty indirectly by increasing the security dimension of their website (Ribbink et al, 2004).

Refering to Chiang and Jang (2007) who found that brand image has a positive effect to trust, we thus can say that trust can be leveraged using brand image. Brand image increases consumers' trust since it can reduce risks of buying. Offering brand image along with marketing strategies associated with it helps consumers connecting the image to their minds. Trust possibly mediates the influence of brand image toward e-loyalty.

The research model built on the literature review is as presented in figure 1.

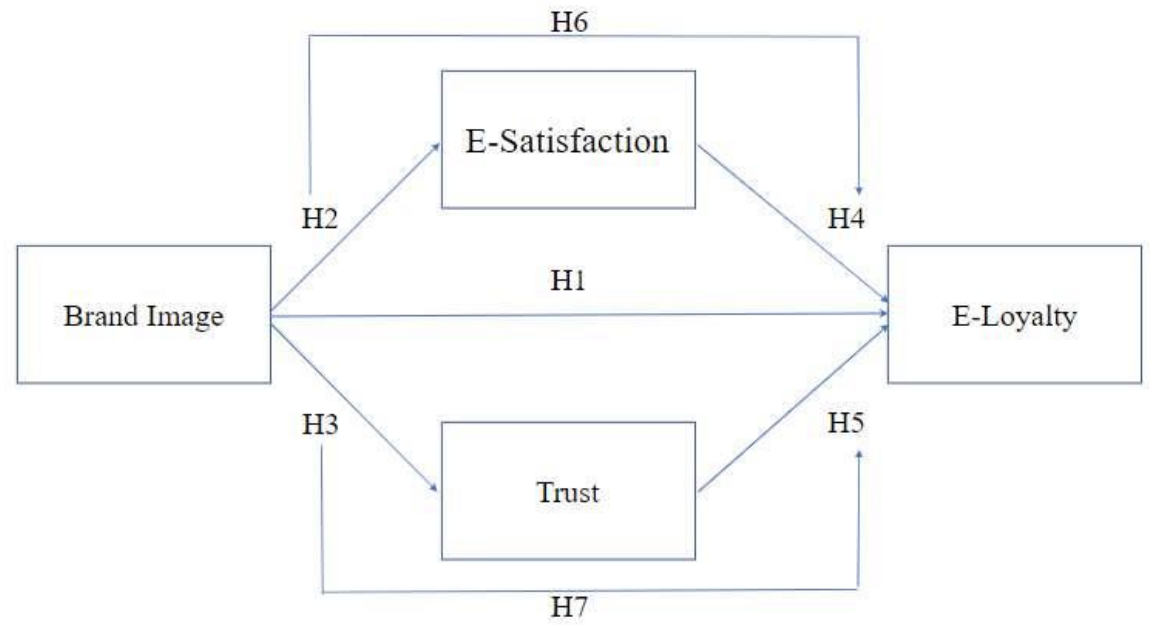

Figure 1. Research Framework

\section{METHODS}

\section{Population and Sample}

This research applied quantitative approach using survey to examine the factors influencing e-loyalty in the case of Tokopedia. All users of Tokopedia in Indonesia is the 
population (Sugiyono, 2017), which comprise of total 90 million people (Kumparan, 2019). Since the size is too big, samples are considered (Siswanto \& Suyono, 2018). Sample size was determined according to Hair Jr. et al (2014), in which it depends on the number of indicators (n) ranging from $(\mathrm{nx} 5)$ to $(\mathrm{nx} 10)$. With $\mathrm{n}=14$, the number of sample was thus between 70 and 140.

Respondents were selected using purposive sampling with the criteria: users who purchased from Tokopedia for at least twice within the last two months at the time of survey and who are classified as Generation Y and Z which were born between 1980 and 2000 (Jiang, 2019) since they are the most users of e-commerce (Muazam, 2020).

\section{Data Collection Method}

The questionnaire as a mean to collect data was created using Google form and contains questions in 5-point Likert ranging from 1-strongly disagree to 5-strongly agree. It was distributed by sending the links to the intended respondents through email and social media. A comment about the questionnaire link put on official Tokopedia account posted on Twitter and Instagram spreaded the questionnaire simultaneously until the maximum number of respondents was met. Of the 140 returned questionnaires, only 112 were complete. The next process used the information from 112 respondents.

Prior to the distribution, the questionnaire was tested for its validity using Pearson Product Moment correlation (Siswanto \& Suyono, 2018). All items in the questionnaire are evidently valid since each has sig 0.000 which lower than 0.05 and the correlation (r) $>0.192$ at $5 \%$ level of significant (see Table 1). 
Table 1. Validity Test

\begin{tabular}{|c|c|c|}
\hline Variable & Item & Correlation \\
\hline $\begin{array}{c}\text { Brand Image } \\
\text { (X) }\end{array}$ & $\begin{array}{l}\text { Perceived popularity of Tokopedia } \\
\text { Perceived good reputation of Tokopedia } \\
\text { Perceived of ease of use of the application }\end{array}$ & $\begin{array}{l}0.829 \\
0.789 \\
0.779\end{array}$ \\
\hline $\begin{array}{l}\text { E-Satisfaction } \\
\text { (M1) }\end{array}$ & $\begin{array}{l}\text { Perceived enjoyment of a transaction in Tokopedia } \\
\text { Perceived conformity of expectation } \\
\text { Perceived suitability of the service }\end{array}$ & $\begin{array}{l}0.889 \\
0.893 \\
0.881\end{array}$ \\
\hline $\begin{array}{l}\text { Trust } \\
\text { (M2) }\end{array}$ & $\begin{array}{l}\text { Perceived accountability of the transactions security } \\
\text { Perceived level of success in a transaction } \\
\text { Perceived suitability of Tokopedia's claims about the } \\
\text { services } \\
\text { Perceived suitability of Tokopedia's promises on the } \\
\text { services }\end{array}$ & $\begin{array}{l}0.824 \\
0.807 \\
0.884\end{array}$ \\
\hline $\begin{array}{c}\text { E-Loyalty } \\
\text { (Y) }\end{array}$ & $\begin{array}{l}\text { Frequency in using Tokopedia for searching goods } \\
\text { compare other e-commerce } \\
\text { Repurchase intention within the last two months } \\
\text { Eagerness to switch to another e-commerce } \\
\text { Positive e-WOM toward at least one acquaintance }\end{array}$ & $\begin{array}{l}0.694 \\
0.750 \\
0.714\end{array}$ \\
\hline
\end{tabular}

Source: Primary data, 2020

The reliability test using split-half method resulted in the questionnaire (Siswanto \& Suyono, 2018) is a reliable tool for collecting data. Table 2 shows each variable has value of reliability that is higher than 0.192 at $5 \%$ level of significance.

Table 2. Reliability test

\begin{tabular}{|l|r|}
\hline \multicolumn{1}{|c|}{ Variable } & Reliability Value \\
\hline Brand Image & 0.719 \\
e-Satisfaction & 0.850
\end{tabular}




\begin{tabular}{|l|r|}
\hline \multicolumn{1}{|c|}{ Variable } & Reliability Value \\
\hline Trust & 0.852 \\
e-Loyalty & 0.759 \\
\hline
\end{tabular}

Source: Primary data, 2020

\section{Data Analysis Method}

Prior to regression, the data were tested for their accuracy in resulting best regression. Classic assumption tests applied for this purpose comprise of normality, heteroscedasticity, multicollinearity, and autocorrelation. Normality test using Kolmogorov-Smirnov (K-S) indicates data is distributed with normal if the significance > 0.05 (Ghozali, 2016). Multicollinearity test for testing existence of correlations between the independent variables (Ghozali, 2016) was conducted using tolerance value and variance inflation factor (VIF). Multicollinearity exists if tolerance value $<10 \%$ and VIF $>10$. Heteroscedasticity test is to detect presence of inequality in the residual variants from one observation to another (Ghozali, 2016) that was observed from patterns of the scatterplot graph between the SRESID residual and the predictive value of the dependent variable (dependent) ZPRED. If the scatter indicates a particular pattern, then heteroscedasticity exists, and otherwise.

Mediating Regression Analysis (MRA) was applied to see whether e-satisfaction and trust affects the influence of brand image (independent variable) on e-loyalty (dependent variable). Referring to Baron and Kenny (1986) regarding to the procedure for this analysis, 3 regression models were created to test the mediating effect on the model $Y=\alpha_{1}+c X$

- Model 1: $\mathrm{M}_{1}=\alpha_{2}+\mathrm{aX}$

- Model 2: $\mathrm{M}_{2}=\alpha_{2}+\mathrm{aX}$

- Model 3: $\mathrm{Y}=\alpha_{3}+\mathrm{c}^{\prime} \mathrm{X}+\mathrm{bM}_{\mathrm{i}}$ 
in which $\mathrm{Y}=\mathrm{e}-$ Loyalty; $\mathrm{M}_{1}=\mathrm{e}-$ Satisfaction $\mathrm{M}_{2}=$ Trust; $\mathrm{X}=$ Brand Image; $\alpha=$ constant; $\mathrm{a}, \mathrm{b}$, $c$, and $c^{\prime}=$ coefficient value; $i=1,2$.

The variable $M$ is a mediator if $c \neq 0 ; a \neq 0$; and $b \neq 0$.

Following this, Sobel test was applied to find out the influence of a mediating variable (e-Satisfaction or Trust) between Brand Image and e-Loyalty.

$$
z=\frac{a b}{\sqrt{\left(b^{2} S E a^{2}\right)+\left(a^{2} S E b^{2}\right)}}
$$

in which $\mathrm{a}$ and $\mathrm{b}=$ regression coefficient; $\mathrm{SE}_{\mathrm{i}}=$ standard error of estimation $\mathrm{i}$.

Mediating effect occurs when the $\mathrm{z}>\mathrm{z}$ table of 1.96 (significance level of $\alpha=0.05$ ).

In order to determine whether the mediation is perfect or partial, the indirect effect equation was applied.

$$
\mathrm{c}=\mathrm{c}^{\prime}+\mathrm{ab}
$$

Perfect mediation occurs if the effect of $\mathrm{X}$ to $\mathrm{Y}(\mathrm{c})$ decreases to zero after inserting $\mathrm{M}$ into the regression equation ( $a$ and $b$ ) or $c^{\prime}$ is not significant. Partial mediation occurs if the effect of $X$ to $\mathrm{Y}$ decreases but is not equal to zero after including $\mathrm{M}$ or $\mathrm{c}^{\prime}$ is significant.

t-test was conducted to test significance influence of independent variable to dependent variable at $\alpha=0.05$. The variable has a significant effect if the Sig value $<0.05$ and vice versa.

Coefficient of determination $\left(\mathrm{R}^{2}\right)$ was applied to measure ability of the model in explaining variations in the dependent variable. The ability is higher if the value of $\mathrm{R}^{2}$ is approaching 1 and it is lower if $\mathrm{R}^{2}$ is approaching 0 .

\section{RESULTS AND DISCUSSION}

\section{Characteristics of the Respondents}

Majority of the respondents are female (55\%), were still pursuing their study as students $(58 \%)$ and working mainly in private organizations (31\%). Their monthly income was less than 
15 million rupiahs in general. As the buyer of Tokopedia, they predominantly bought fashion $(18 \%)$, electronics $(11 \%)$, and beauty products $(9 \%)$

\section{Classical Assumption Tests}

The tests were used to estimate if the regression is BLUE (best linear unbiased estimator), meaning that there is no heteroscedasticity, no multicollinearity, and no autocorrelation. Table 3 presents the results of normality test on three regression models. Since each model results in Sig. KS > 0.05 indicating that the residual model is distributed normally, the data is thus eligible for this research.

Table 3. Normality Test on the Regression Models

\begin{tabular}{|ll|r|r|r|}
\hline \multirow{2}{*}{} & & \multicolumn{3}{|c|}{ Unstandardized Residual } \\
\cline { 3 - 5 } & & Model 1 & \multicolumn{1}{c|}{ Model 2 } & \multicolumn{1}{c|}{ Model 3 } \\
\hline Normal & Mean & 114 & 114 & 114 \\
Parameters $^{\mathrm{a}}$ & Std. Deviation & .0000000 & .0000000 & .0000000 \\
Most Extreme & Absolute & 1.47171899 & 1.96317026 & 2.44522060 \\
Differences & Positive & .096 & .096 & .080 \\
& Negative & .089 & .096 & .052 \\
& -.096 & -.078 & -.080 \\
Kolmogorov-Smirnov Z & 1.024 & 1.030 & .0852 \\
Asymp. Sig. (2-tailed) & .245 & .239 & .462 \\
\hline
\end{tabular}

a. Test distribution is Normal.

Source: Data processed, 2020

The scatterplots figure 2 indicate that distribution of residuals in each model does not form particular pattern. It can thus be concluded that there is no heteroscedasticity problem in each model. 


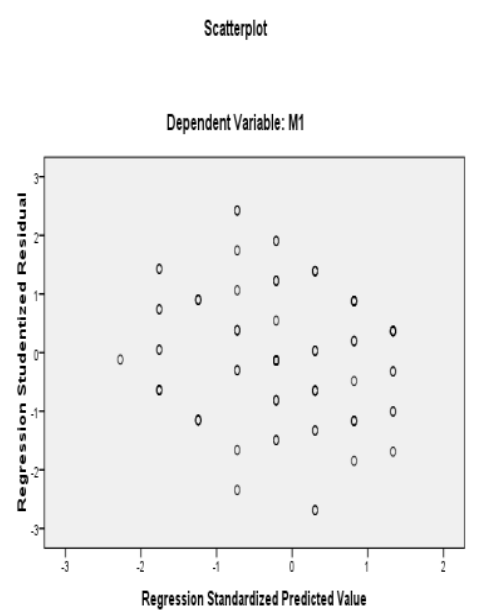

Model 1

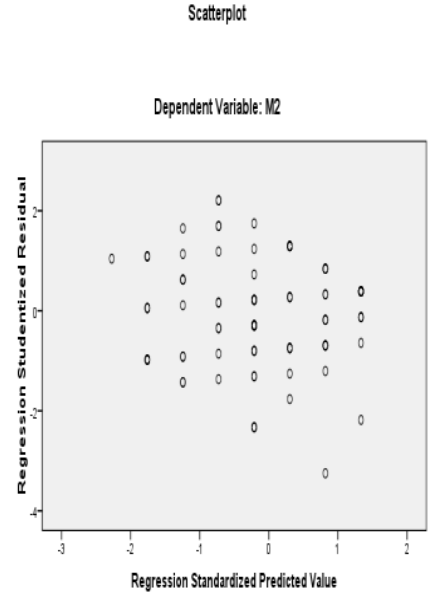

Model 2

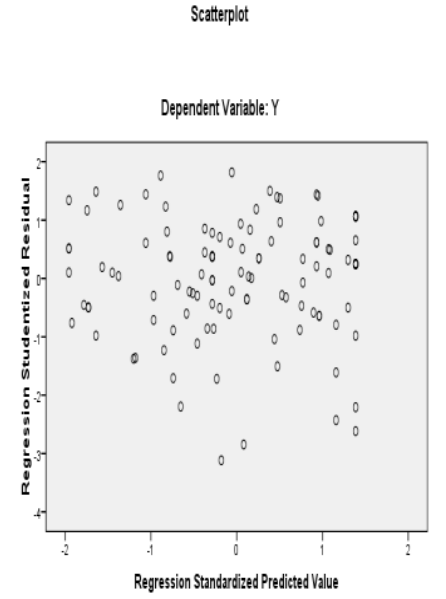

Model 3

Figure 2. Heteroscedasticity Test on the Regression Models

Multicolinierity test on model 3 results in the tolerance value $>0.10$ and VIF less than 10. It can thus be concluded that multicollinearity does not exist between the independent variables.

Table 4. Multicolinierity Test on the Regression Model 3

Coefficients $^{\mathrm{a}}$

\begin{tabular}{|c|c|c|c|}
\hline \multirow{2}{*}{\multicolumn{2}{|c|}{ Model }} & \multicolumn{2}{|c|}{ Collinearity Statistics } \\
\hline & & Tolerance & VIF \\
\hline \multirow[t]{4}{*}{1} & (Constant) & & \\
\hline & $X$ & .454 & 2.202 \\
\hline & M1 & .382 & 2.617 \\
\hline & M2 & .429 & 2.332 \\
\hline
\end{tabular}

a. Dependent Variable: Y

Source: Data processed, 2020

The classical assumption tests indicate that the data can be used further for regression analysis that lead to unbiased result of analysis. 


\section{Results on Mediating Regression Analysis}

The mediating regression analysis was applied to see whether e-satisfaction and trust affects the influence of brand image toward e-loyalty. The analysis on the three models results in the following equations (refer to table 4)

- $\mathrm{M}_{1}=3.116+0.757 \mathrm{X}+\mathrm{e}$

- $\mathrm{M}_{2}=5.860+0.893 \mathrm{X}+\mathrm{e}$

- $\mathrm{Y}=0.788+0.453 \mathrm{X}+0.422 \mathrm{M}_{1}+0.174 \mathrm{M}_{2}+\mathrm{e}$

Since significance of model 1 is 0.000 , it means that brand image positively and significantly affects e-satisfaction. Similarly happens to model 2 that results also in significance of 0.000 . Hence, it can be concluded that we can accept that brand image positively and significantly affects trust is thus accepted. Model 3 shows different result. Even though brand image, e-satisfaction, and trust respectively give positive effect to e-loyalty, but only brand image and e-satisfaction that give significant effect to e-loyalty, while trust insignificantly affects e-loyalty (sig 0.203). Hence, we can accept that brand image and e-satisfaction respectively affects e-loyalty positively and significantly. On the other side, we reject if trust positively and significantly affects e-loyalty.

Table 5. Regression Result of the Models

\begin{tabular}{|c|c|c|c|c|c|}
\hline \multirow[b]{2}{*}{ Model } & \multicolumn{2}{|c|}{$\begin{array}{c}\text { Unstandardized } \\
\text { Coefficients }\end{array}$} & \multirow{2}{*}{$\begin{array}{c}\text { Standardized } \\
\text { Coefficients } \\
\text { Beta }\end{array}$} & \multirow[b]{2}{*}{$\mathrm{t}$} & \multirow[b]{2}{*}{ Sig. } \\
\hline & B & Std. Error & & & \\
\hline $1^{\mathrm{a}} \quad$ (Constant) & 3.116 & .900 & & 3.462 & .001 \\
\hline$X$ & .757 & .072 & .706 & 10.561 & .000 \\
\hline $2^{\mathrm{b}} \quad$ (Constant) & 5.860 & 1.201 & & 4.881 & .000 \\
\hline$X$ & .893 & .096 & .662 & 9.338 & .000 \\
\hline $3^{\mathrm{c}} \quad$ (Constant) & .788 & 1.671 & & .471 & .638 \\
\hline
\end{tabular}




\begin{tabular}{|c|c|c|c|c|c|}
\hline \multirow[b]{2}{*}{ Model } & \multicolumn{2}{|c|}{$\begin{array}{c}\text { Unstandardized } \\
\text { Coefficients }\end{array}$} & \multirow{2}{*}{$\begin{array}{c}\begin{array}{c}\text { Standardized } \\
\text { Coefficients }\end{array} \\
\text { Beta }\end{array}$} & \multirow[b]{2}{*}{$\mathrm{t}$} & \multirow[b]{2}{*}{ Sig. } \\
\hline & B & Std. Error & & & \\
\hline$X$ & .453 & .178 & .279 & 2.541 & .012 \\
\hline M1 & .422 & .181 & .278 & 2.327 & .022 \\
\hline M2 & .174 & .136 & .145 & 1.281 & .203 \\
\hline
\end{tabular}

a. Dependent Variable: M1

b. Dependent Variable: M2

c. Dependent Variable: Y

Source: Data processed, 2020

\section{Coefficient of Determination}

This analysis was to see goodness of the model in explaining variation of e-loyalty caused by brand image, e-satisfation, and trust. Model 1 shows contribution of brand image (X) towards variation of e-satisfaction $\left(\mathrm{M}_{1}\right)$ is $49.9 \%$. This indicates that there are other variables influencing e-satisfaction other than brand image, which give contribution of $50.1 \%$. Similarly, model 2 also indicate other variables contributing to variation of trust since brand image $(\mathrm{X})$ has contribution of only $43.8 \%$ towards variation of trust $\left(\mathrm{M}_{2}\right)$. Meanwhile $56.2 \%$ remaining are determined by other variables not covered in this model.

Model 3 examining contribution of brand image (X), e-satisfaction $\left(\mathrm{M}_{1}\right)$, and trust $\left(\mathrm{M}_{2}\right)$ results in a contribution of $39.8 \%$ towards e-loyalty $(\mathrm{Y})$. This means that $60.2 \%$ remaining is determined by other variables out of this model.

Table 6. Coefficient of Determination Result of the Models

\begin{tabular}{|l|r|r|r|r|}
\hline Model & R & R Square & \multicolumn{1}{|c|}{$\begin{array}{c}\text { Adjusted R } \\
\text { Square }\end{array}$} & $\begin{array}{c}\text { Std. Error of } \\
\text { the Estimate }\end{array}$ \\
\hline $1^{\mathrm{a}}$ & $.706^{\mathrm{a}}$ & .499 & .494 & 1.47827 \\
$2^{\mathrm{b}}$ & $.662^{\mathrm{b}}$ & .438 & .433 & 1.97191 \\
\hline
\end{tabular}




\begin{tabular}{|l|r|r|r|r|}
\hline Model & R & R Square & \multicolumn{1}{|c|}{$\begin{array}{c}\text { Adjusted R } \\
\text { Square }\end{array}$} & $\begin{array}{c}\text { Std. Error of } \\
\text { the Estimate }\end{array}$ \\
\hline $3^{\mathrm{c}}$ & $.631^{\mathrm{c}}$ & .398 & .382 & 2.47834 \\
\hline
\end{tabular}

a. Predictors: (Constant), X; Dependent Variable: $\mathrm{M}_{1}$

b. Predictors: (Constant), X; Dependent Variable: $\mathrm{M}_{2}$

c. Predictors: (Constant), $\mathrm{M}_{2}, \mathrm{X}, \mathrm{M}_{1}$ Dependent Variable: $\mathrm{Y}$

Source: Data processed, 2020

\section{Indirect Effect Test}

Sobel test was applied to find out whether e-satisfaction and trust mediates between brand image and e-loyalty. Sobel test on mediating effect of e-satisfaction in brand image towards e-loyalty results in $\mathrm{z}$ value $=2.2761>1.96(\mathrm{z}$ table value with significance level of $\alpha$ $=0.05)$. It can be concluded that there is a significant mediating effect of the $\mathrm{M}_{1}$ (e-satisfaction) in the relationship of $\mathrm{X}$ (brand image) and $\mathrm{Y}$ (e-loyalty). Hence, we accept that brand image significantly affects e-loyalty through e-satisfaction as a mediating variable is accepted. However, with $c^{\prime}=0.134$, the effect is only partial mediation.

The opposite result is shown by trust. $Z$ value on mediating effect of trust in brand image towards e-loyalty is 1.267 which is lower than the threshold 1.96 . This indicates that there is no a significant mediating effect of the $\mathrm{M}_{2}$ (trust) variable in the relationship $\mathrm{X}$ (brand image) to Y (e-loyalty). Hence, it can be stated that brand image significantly affects e-loyalty through trust as a mediating variable is rejected.

\section{Discussion}

The findings of this research support previous studies. As Ogba \& Tan (2009) found, this study also found the influence of brand image on e-satisfaction and e-loyalty. Moreover, in line with the study of Lien et al (2015) and of Hsu (2013), e-satisfaction was also found as having positive and significant effect on e-loyalty. Mediating effect analysis resulted in partial 
mediation of e-satisfaction between brand image and e-loyalty. This means that e-satisfaction bridged the influence of brand image towards e-loyalty even though brand image also affects e-loyalty directly.

In relation to trust, the results of this study also supports those of Lien et al (2015) which stated that brand image affects trust, but trust does not significantly affect e-loyalty. The study of Sadeghi et al (2018) put more emphasis on the latter, which is trust does not affect e-loyalty significantly. Referring to Baron and Kenny (1986), if there is no influence among one of the paths, thus the mediating effect does not occur. In other words, trust does not mediate brand image and e-loyalty. The possibility of this insignificant effect of trust to e-loyalty on Tokopedia is the case of user data breach revealed in the mid of 2020. This case might have influence on the respondents' perception on trust to Tokopedia during the data collection conducted in November 2020. The breach occurred because of the internal security imperfection which indicated lack of competence of Tokopedia. Furthermore, since the acknowledgment and reconciliation conducted by Tokopedia is considered as low, it needs time to restore the level of trust. This is in accordance to the study of Choi \& Nazareth (2014) on trust violation and the reconciliation acts. They found that the moderate severity offenses caused by lack of competence with a low reconciliation act are relatively slow way to build-back trust since customers are possibly prone to seek alternatives. This results in lack of e-loyalty.

\section{CONCLUSION AND IMPLICATIONS}

The study support the previous studies on the effect of brand image and e-satisfaction toward e-loyalty of Tokopedia users. Each affects e-loyalty positively and significantly. Nevertheless, it is found that e-satisfaction mediates the effect of brand image to e-loyalty partially. This indicates that Tokopedia users become loyal to Tokopedia since they found 
satisfaction on the transaction conducted in Tokopedia that they chose because of its good brand image. However, trust does not take effect on e-loyalty of Tokopedia users.

For Tokopedia, maintaining good brand image is a good way to generate e-loyalty. It can collaborate with a good image and popular brand ambassador in order to raise brand awareness and represent Tokopedia in public. Tokopedia is also expected to maintain its service quality by increasing willingness to listen to the feedbacks from the customers. Even though trust does not significantly affect e-loyalty, Tokopedia still needs to put concerns on security of users' data and to give quick response for giving the users safety in doing transactions in Tokopedia.

Future research should cover variables other than brand image, e-satisfaction, and trust as the antecedents to e-loyalty since they can only predict variations on e-loyalty as much as 39.8\%. Moreover, since this research explored e-loyalty from the customers' perspective and emarketplace is not only about relation between the company and customers but also the sellers, so exploring e-loyalty from sellers' perspective is appealing to do. Future research can possibly be conducted in other e-marketplaces or other e-commerce with a more segmented market such as fashion e-commerce, gadget e-store, or specific brand web-store.

\section{REFERENCES}

Aaker, D. A. (1996). Measuring brand equity across products and markets. California Management Review, 38(3), 102-120. doi: https://doi.org/10.2307/41165845

Aghekyan-Simonian, M., Forsythe, S., Suk Kwon, W., \& Chattaraman, V. (2012). The role of product brand image and online store image on perceived risks and online purchase intentions for apparel. Journal of Retailing and Consumer Services, 19(3), 325-331. https://doi.org/10.1016/j.jretconser.2012.03.006

Ahmad, A., Rahman, O., \& Khan, M. N. (2017). Exploring the role of website quality and hedonism in the formation of e-satisfaction and e-loyalty: Evidence from internet users in India. Journal of Research in Interactive Marketing, 11(3), 246-267. https://doi.org/10.1108/JRIM-04-2017-0022 
Al-dweeri, R. M., Obeidat, Z. M., Al-dwiry, M. A., Alshurideh, M. T., \& Alhorani, A. M. (2017). The Impact of E-Service Quality and E-Loyalty on Online Shopping: Moderating Effect of E-Satisfaction and E-Trust. International Journal of Marketing Studies, 9(2), 92. https://doi.org/10.5539/ijms.v9n2p92

Anderson, R. E., \& Srinivasan, S. S. (2003). E-Satisfaction and E-Loyalty: A Contingency Framework. Psychology and Marketing, 20(2), 123-138. https://doi.org/10.1002/mar.10063

Audrain-Pontevia, A. F., N'Goala, G., \& Poncin, I. (2013). A good deal online: The Impacts of acquisition and transaction value on E-satisfaction and E-loyalty. Journal of Retailing and Consumer Services, 20(5), 445-452. https://doi.org/10.1016/j.jretconser.2013.04.002

Azam, A. (2015). Investigation of psychological dimensions of trust on e-loyalty A case of Saudi Arabia consumers. Journal of Islamic Marketing, 6(2), 224-249.

Baron, R. M., \& Kenny, D. A. (1986). The moderator-mediator variable distinction in social psychological research: Conceptual, strategic, and statistical considerations. Journal of Personality and Social Psychology, 51(6), 1173-1182. https://doi.org/10.1037/00223514.51.6.1173

Bian, X., \& Moutinho, L. (2011). The role of brand image, product involvement, and knowledge in explaining consumer purchase behaviour of counterfeits: Direct and indirect effects. European Journal of Marketing, 45(1), 191-216. https://doi.org/10.1108/03090561111095658

Bilgihan, A. (2016). Gen y customer loyalty in online shopping: An integrated model of trust, user experience and branding. Computers in Human Behavior, 61, 103-113. https://doi.org/10.1016/j.chb.2016.03.014

Carter, M., Wright, R., Thatcher, J. B., \& Klein, R. (2014). Understanding online customers' ties to merchants: The moderating influence of trust on the relationship between switching costs and e-loyalty. European Journal of Information Systems, 23(2), 185204. https://doi.org/10.1057/ejis.2012.55

Chang, H. H., Wang, Y. H., \& Yang, W. Y. (2009). The impact of e-service quality, customer satisfaction and loyalty on e-marketing: Moderating effect of perceived value. Total Quality Management and Business Excellence, 20(4), 423-443. Doi: https://doi.org/10.1080/14783360902781923

Chiang, C.-F., \& Jang, S. S. (2007). The Effects of Perceived Price and Brand Image on Value and Purchase Intention: Leisure Travelers' Attitudes Toward Online Hotel Booking. Journal of Hospitality \& Leisure Marketing, 15(3), 49-69. Doi: https://doi.org/10.1300/J150v15n03_04

Cyr, D., Bonanni, C., Bowea, J., \& Ilsever, J. (2005). Beyond trust: Web site design preferences across cultures. Journal of Global Information Management, 13(4), 25-54. https://doi.org/10.4018/jgim.2005100102 
Gefen, D. (2002). Customer Loyalty in E-Commerce. Journal of the Association for Information Systems, 3, 27-51.

Ghozali, I., \& Chariri, A. (2016). Teori Akuntansi Internasional Financial Reporting Systems (IFRS). In

Hapsari, R., Clemes, M. D., \& Dean, D. (2017). The impact of service quality, customer engagement and selected marketing constructs on airline passenger loyalty. International Journal of Quality and Service Sciences, 9(1), 21-40. https://doi.org/10.1108/IJQSS-07-2016-0048

Hair Jr, J. F., Black, W. C., Babin, B. J., \& Anderson, R. E. (2014). Multivariate Data Analysis (7th Edition). Essex: Pearson.

Huang, L. (2008). Exploring the determinants of E-loyalty among travel agencies. Service Industries Journal, 28(2), 239-254. Doi: https://doi.org/10.1080/02642060701842316

Hsu, L. C., Wang, K. Y., \& Chih, W. H. (2013). Effects of web site characteristics on customer loyalty in B2B e-commerce: Evidence from Taiwan. Service Industries Journal, 33(11), 1026-1050. Doi: https://doi.org/10.1080/02642069.2011.624595

Jiang, S. (2019, April 2). The ABCs of Generations X, Y and Z. Forbes human resources council. Forbes. Retrieved on August 21st 2020 from https://www.forbes.com/sites/forbeshumanresourcescouncil/2019/04/02/the-abcs-ofgenerations- $\mathrm{x}-\mathrm{y}$-and-z/?sh=2caae $8 \mathrm{c} 3672 \mathrm{~b}$

Keller, K. L. (2013). Strategic Brand Management: Building, Measuring, and Managing Brand Equity (4th ed.). Essex: Pearson.

Kotler, P., \& Keller, K. L. (2016). Marketing Management Global Edition15th Edition. (Vol. 15E). doi: https://doi.org/10.1080/08911760903022556

Kumparan. (2019, September 20). Jumlah Pengguna Aktif Bulanan Tokopedia Capai 90 Juta. Kumparan. Retrieved on August 28th 2020 from https://kumparan.com/kumparantech/jumlah-pengguna-aktif-bulanan-tokopediacapai-90-juta-1rts9HySrXa/full

Lee, H., Choi, S. Y., \& Kang, Y. S. (2009). Formation of e-satisfaction and repurchase intention: Moderating roles of computer self-efficacy and computer anxiety. Expert Systems with Applications, 36(4), 7848-7859. Doi: https://doi.org/10.1016/j.eswa.2008.11.005

Lien, C. H., Wen, M. J., Huang, L. C., \& Wu, K. L. (2015). Online hotel booking: The effects of brand image, price, trust and value on purchase intentions. Asia Pacific Management 20(4), Review, 210-218. Doi: https://doi.org/10.1016/j.apmrv.2015.03.005

Moriuchi, E., \& Takahashi, I. (2016). Satisfaction trust and loyalty of repeat online consumer within the Japanese online supermarket trade. Australasian Marketing Journal, 24(2), 146-156. Doi: https://doi.org/10.1016/j.ausmj.2016.02.006 
Muazam, A. R. (2020). Transaksi e-commerce didominasi generasi Z dan milenial. Alinea: Gaya hidup. Retrieved from https://www.alinea.id/gaya-hidup/transaksi-e-commercedidominasi-generasi-z-dan-milenial-b1ZRL9woj. Accessed on August 21st 2020.

Ogba, I.-E., \& Tan, Z. (2009). Exploring the impact of brand image on customer loyalty and commitment in China. Journal of Technology Management in China, 4(2), 132-144. https://doi.org/10.1108/17468770910964993

Oliver, R. L. (2010). Satisfaction: A Behavioral Perspective on the Consumer (2nd Ed). https://doi.org/10.4324/9781315700892

O'Neill, J. W., \& Xiao, Q. (2006). The role of brand affiliation in hotel market value. Cornell Hotel and Restaurant Administration Quarterly, 47(3), 210-223. Doi: https://doi.org/10.1177/0010880406289070

Pereira, H. G., Salgueiro, M. de F., \& Rita, P. (2016). Online purchase determinants of loyalty: The mediating effect of satisfaction in tourism. Journal of Retailing and Consumer Services, 30, 279-291. https://doi.org/10.1016/j.jretconser.2016.01.003

Ribbink, D., Riel, A. C. R. Van, Liljander, V., \& Streukens, S. (2004). Comfort your online customer: quality, trust, and loyalty on the internet. Managing Service Quality: An International Journal, 14(6), 446-456.

Sadeghi, A., Ghujali, T., \& Bastam, H. (2018). The effect of organisational reputation on eloyalty: The roles of e-trust and e-satisfaction. Asean Marketing Journal VO - 10, X(1), 1-16. Retrieved from http://journal.ui.ac.id/index.php/amj/article/view/10628/67546345

Safa, N. S., \& Von Solms, R. (2016). Customers repurchase intention formation in e-commerce. SA Journal of Information Management, 18(1), 1-9. doi: https://doi.org/10.4102/sajim.v18i1.712

Shankar, V., Smith, A. K., \& Rangaswamy, A. (2003). Customer satisfaction and loyalty in online and offline environments. International Journal of Research in Marketing, 20(2), 153-175. doi: https://doi.org/10.1016/S0167-8116(03)00016-8

Siswanto., \& Suyanto. (2018). Metodologi penelitian kuantitatif korelasional. Klaten: Bossscript.

Sugiyono. (2017). Metode penelitian bisnis (3rd Edition). Bandung: Alfabeta

Tang, T. W., \& Huang, R. T. (2015). The relationships among trust, e-satisfaction, e-loyalty, and customer online behaviors. International Journal of Business and Industrial Marketing, 1(2).

Toufaily, E., Ricard, L., \& Perrien, J. (2013). Customer loyalty to a commercial website: Descriptive meta-analysis of the empirical literature and proposal of an integrative model. Journal of Business Research, 66(9), 1436-1447. https://doi.org/10.1016/j.jbusres.2012.05.011 
Tsai, H.-T., Huang, H.-C., Jaw, Y.-L., \& Chen, W.-K. (2006). Why on-line customers remain with a particular e-retailer: An integrative model and empirical evidence. Psychology and Marketing, 23(5), 447-464. doi: https://doi.org/10.1002/mar.20121

Uncles, M. D., Dowling, G. R., \& Hammond, K. (2003). Customer Loyalty and Customer Loyalty Programs. Journal of Consumer Marketing, 20(4), 294-316. doi:http://dx.doi.org/10.1108/07363760310483676

Valvi, A. C., \& West, D. C. (2013). E-Loyalty is not all about trust, price also matters: Extending expectation-confirmation theory in bookselling websites. Journal of Electronic Commerce Research, 14(1), 99-123.

Yousafzai, S. Y., Pallister, J. G., \& Foxall, G. R. (2003). A proposed model of e-trust for electronic banking. Technovation, 23(11), 847-860. Doi: https://doi.org/10.1016/S0166-4972(03)00130-5

Ziaullah, M., Feng, Y., \& Akhter, S. N. (2014). E-Loyalty: The influence of product quality and delivery services on e-trust and e-satisfaction in China. International Journal of Advancements in Research \& Technology, 3(10), 20-31. 